\title{
The Technology of Programmed Thermo-mechanical Processing for Structural Steel
}

\author{
Radkevich Mikhail Mikhailovich \\ High School of Machinebuilding, Institute of Machinery, Materials, and Transport, Peter the Great St. Petersburg Polytechnic University \\ (SPbPU), St. Petersburg, Russian Federation
}

Email address:

radmich@mail.ru

To cite this article:

Radkevich Mikhail Mikhailovich. The Technology of Programmed Thermo-mechanical Processing for Structural Steel. American Journal of Mechanical and Materials Engineering. Vol. 5, No. 2, 2021, pp. 35-38. doi: 10.11648/j.ajmme.20210502.13

Received: December 2, 2020; Accepted: January 4, 2021; Published: June 28, 2021

\begin{abstract}
This paper discusses the technology that allows to obtain high-strength products made of structural carbon and alloy steels with hardening processing named the technology of programmed thermo-mechanical processing (PTMP). Targeted material structure research of hot deformation processing makes possible creation of new important technologies of thermo-mechanical processing (TMP). The programmed thermo-mechanical processing objective is to intense growing process of imperfections during thermal processing and plastic deformation of crystalline lattice, which improves structural conditions and mechanical properties of the product. The desired results achieved only by full realignment of the crystal lattice and micro-grain structures, caused by combined mechanical and thermal processing. Therefore, the objective of the programmed thermo-mechanical processing is to combine two technologies: thermal- and mechanical- processing, into a single production process that allows obtaining of rational micro-grain structural conditions of alloy and the appropriate density of crystalline lattice imperfections that increase forges mechanical properties. To achieve fine alloy structure on various levels (sub-, macro- and micro-grain) PTMP technology must provide regulation of deformation intensity and thermal impact to forged material with programmed manufacturing working algorithm. Designed technology aimed to form a crystalline lattice with desired properties, and fixed chemical composition. The combined mechanical and thermal effect, not only leading to a high density of crystalline structure imperfections but also the most importantly provides homogenous recrystallization process throughout the volume of a workpiece, which provides significantly increased mechanical properties of forgings processed by PTMP.
\end{abstract}

Keywords: Thermo, Mechanical, Hardening, Softening, Material, Properties, Quenching, Tempering, Micro-grain, Structure, Crystalline, Lattice, Alloy.

\section{Introduction}

Noted, that the intensity of thermo-mechanical processing of the alloy steels affects such mechanical characteristics as the tensile strengths $\left(\sigma_{\mathrm{b}}, \mathrm{MPa}\right)$ and flow stress $\left(\sigma_{02}, \mathrm{MPa}\right)$ of the forging material. This effect occurs due to the imperfections of crystalline lattice growth in the process of forge. In the case of excessive growth of the crystal lattice imperfections, the process of forging hardening will stops because of the maximum possible deformation presence in the crystal lattice of the alloy.

The internal energy is accumulated due to deformation associated with an excess density of crystal lattice imperfections and proportional to the deformation stress work. It starts softening processes and is determined by the higher deformation temperature. The forging material hardening level always decreases with higher thermal energy.

It is known that any heat treatment process uses a thermal energy exchange mechanism. To achieve the desired mechanical properties it is necessary to provide a certain temperature-time cycle depending of the dimensions and material of the workpiece. As a result, the material of products gets certain phase changes that lead to the formation of a recrystallized micro-grain structure and material mechanical properties significant changes [15].

Based on this, hardening is not even observed at high deformation temperature. Hardening process depends on thermal energy, caused by a decreased imperfections growth 
speed, i.e. the rapid boost of alloy softening because of the recrystallization process appears, and leads to crystalline lattice imperfections removal. Finally, at a certain temperature point, the rate of softening and hardening intersects and the imperfections of the crystal lattice starts to removing during plastic deformation.

Thermo-mechanical hardening processes associated with the formation of polygonized micro-grain structures with a relatively large rate of hardness and durability. With further mechanical and thermal impact, hardening converts into low softening process. When this happens the redistribution and annihilation of crystal lattice imperfections and dynamic softening appear.

The fluctuations of internal stresses are periodically observed at a relatively low deformation intensity and established phase of the alloy regarding the internal thermal energy. These fluctuations are enough to start the recrystallization process.

Increased thermal energy and further mechanical deformation of crystalline lattice start the formation process of recrystallization centers. This process happens simultaneously in each single volume of uneven deformable material. It leads forging material to polygonal structure growth and internal stress drops.

As the deformation temperature is reduced, crystalline structure imperfections redistribution speed is decreasing as well as softening processes. This also intensifies the hardening process, which requires highly intensive deformation to initiate the low softening process.

The PTMP optimal operating deformation degrees are in the range from $20 \%$ to $40 \%$, with a certain thermal impact for different steel types.

Usage of the optimal operating mods allows to achieve polygonal, uniaxial and stable micro-grain structure of forging material and is characterized by a solid-state stage of alloy.

Processes such as hot die forging, rolling, extrusion, etc. are high-pressure thermo-mechanical processes and these lead to high internal stress of alloy micro-grain structure. To archive the desired increase of mechanical properties of forging material it is necessary to use the programmed TMP production cycle. [9-14].

The influence of deformation intensity on the hardening process depends on deformation temperature as well. Thus, in the area of low temperatures, when the softening is almost non-existent, the hardening process strongly depends on deformation intensity. [8].

At the average processing temperatures, hardening and softening processes are almost equal. Therefore, desired forging material mechanical properties are fully dependent on deformation intensity.

The recrystallization process influence on softening at sufficiently high temperatures and low deformation rates can be so high that deformation will not be accompanied by hardening at all. Nevertheless, the thermal process of softening will not be able to completely proceed at a highly intensive deformation. $[6,7]$.

\section{Results and Discussion}

\subsection{PTMP Processing Modes}

The most significant qualitative influence on the mechanical properties of steels after PTMP is observed at low-temperature deformation and large post-deformation pauses. Therefore, hammer stamping steel forgings $45 \mathrm{Cr}$ at a $5.0 \mathrm{~m} / \mathrm{s}$ speed, $850^{\circ} \mathrm{C}$ temperature, $40 \mathrm{~s}$ post-deformation pause provides hardness HRC 59 after quenching and HRC 41 after tempering. Tensile strength equal to $1335 \mathrm{MPa}$, flow stress - $1222 \mathrm{MPa}$, relative extension 9.8\%, relative compression $-28 \%$, toughness - $1360 \mathrm{~kJ} / \mathrm{m}^{2}$.

While stamping on crank press with the speed of $0.5 \mathrm{~m} / \mathrm{s}$, under the same conditions the hardness after quenching is HRC 49, after the tempering - HRC 46. Tensile strength is equal to $1546 \mathrm{MPa}$, flow stress - $1449 \mathrm{MPa}$, relative extension $-9 \%$, a relative compression is $43 \%$, toughness $499 \mathrm{~kJ} / \mathrm{m}^{2}$.

For steel 20Cr13, the effect of hardening under PTMP does not depend on the deformation intensity with an optimal temperature-time mode. This fact is consistent with the results of the authors. [3, 5].

The PTMP takes place in accord with structural transformations, affected by thermal impact and mechanical deformation, causing significant impact on phase transformations.

Increasing mechanical deformation intensity in distance from the martensitic transformation optimal temperature-time mode leads to more active austenite structural transformations proceeding. In addition, the deformed austenite structure has a significant impact on the martensitic transformation.

So, if the main PTMP modes are properly adjusted, principles of phase transformations are taken into account, they can result not only into a specific type of the forging material micro-grain structure (pearlite, sorbitol, troostit, bainite, or martensite), but also into its homogeneous property. [1, 4].

\subsection{Tested Steels and the Resulting Mechanical Properties}

The results of studies on the effect of the thermomechanical processing (TMO) of structural and phase transformations based on modern ideas about the crystalline imperfections structure led to the technology of programmed thermo-mechanical processing (PTMP) development along with technological schemes for hot deformation of forgings.

The main condition for the implementation of programmed thermo-mechanical processing is the regulation of the postdeformation pause period with strict fixation of the deformation temperature and rate of deformation intensity depending on the steel type.

The PTMP of workpieces manufacturing for three major steel types (20Cr13, 08Cr18Ni10Ti and.45Cr) with optimal modes allows processing high strength products, i.e. heavily loaded machine elements (figure 1). 


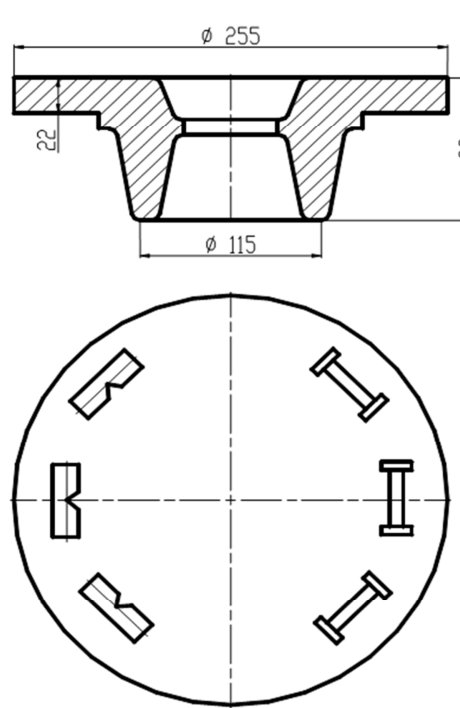

a) the flange

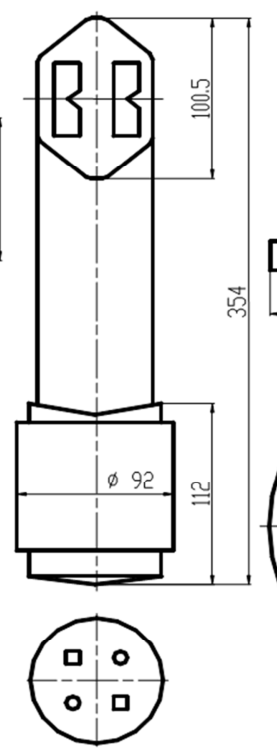

b) fork sliders

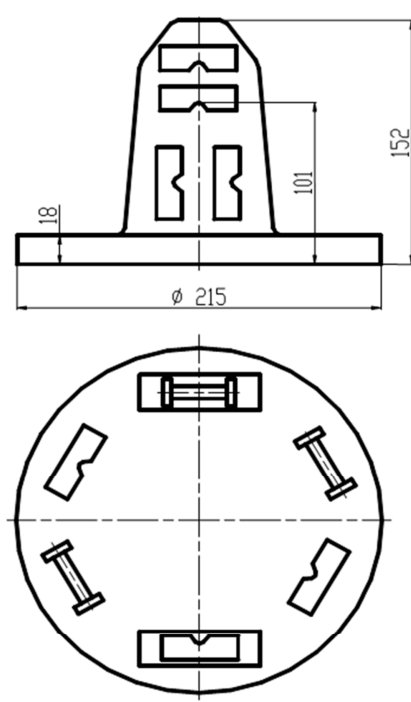

c) flange-plug

Figure 1. Forgings made by hot volume stamping on the crank press and hammer using PTMP and the scheme of cutting samples for mechanical tests.

The mechanical properties comparison for standard mode punching with subsequent quenching and tempering is submitted in table 1.

Table 1. Comparison of forgings mechanical properties for standard mode punching.

\begin{tabular}{|c|c|c|c|c|c|c|}
\hline $\begin{array}{l}\text { № } \\
\text { mode }\end{array}$ & $\begin{array}{l}\text { Name of } \\
\text { forgings, steel }\end{array}$ & $\begin{array}{l}\text { Heating } \\
\text { Temperature }\end{array}$ & $\begin{array}{l}\begin{array}{l}\text { Deformation } \\
\text { temperature }\end{array} \\
\text { tempere }\end{array}$ & $\begin{array}{l}\text { Cooling } \\
\text { time, } s\end{array}$ & Coolant fluid & Heating conditions \\
\hline 1 & Flon $23 \mathrm{Cr} \mathrm{Ci}$ & 1100 & 950 & 30 & Oil & Tempering $580^{\circ} \mathrm{C}, 2$ hours, water \\
\hline 2 & Flange $33 \mathrm{Crs} 1$ & 1260 & 1100 & - & Air & Quenching $910^{\circ} \mathrm{C}$ with oil. Tempering $580^{\circ} \mathrm{C}, 2$ hours, water \\
\hline 3 & Flano plu 15 & 1100 & 900 & 30 & Oil & Tempering $600^{\circ} \mathrm{C}, 2$ hours, water \\
\hline 4 & Flange-plug, 45 & 1260 & 1100 & - & Air & Quenching $860^{\circ} \mathrm{C}$ with oil. Tempering $600^{\circ} \mathrm{C}, 2$ hours, water \\
\hline 5 & Fork sliders, & 1260 & 950 & 30 & Oil & Tempering $650^{\circ} \mathrm{C}, 2$ hours, water \\
\hline 6 & $40 \mathrm{CrSi}$ & 1260 & 1260 & - & Air & Quenching $910^{\circ} \mathrm{C}$ with oil. Tempering $650^{\circ} \mathrm{C}, 2$ hours, water \\
\hline
\end{tabular}

Note: 1, 3, 5 forgings mechanical characteristics obtained by PTMP modes; 2, 4, 6, factory modes.

The results of mechanical tests and samples mechanical properties comparison after PTMP and standard thermal processing of steels are submitted in table 2.

Table 2. Comparison of forgings mechanical properties after PTMP and standard mode punching.

\begin{tabular}{|c|c|c|c|c|c|}
\hline № mode & Tensile strengths $\sigma_{\mathrm{b}}$, MPa & Flow stress $\sigma_{02}, \mathrm{MPa}$ & Relative extension $\delta, \%$ & Relative compression $\psi, \%$ & Toughness KCU, KJ/m² \\
\hline \multicolumn{6}{|c|}{ Flange forgings, steel $33 \mathrm{CrSi}$} \\
\hline 1 & 1120 & 980 & 16.5 & 49.5 & 410 \\
\hline 2 & 1070 & 931 & 15.0 & 47.0 & 360 \\
\hline \multicolumn{6}{|c|}{ Forging flange-plug, steel 45} \\
\hline 3 & $750 / 750$ & $461 / 450$ & $21.0 / 22.0$ & $61.0 / 63.5$ & $960 / 880$ \\
\hline 4 & $680 / 700$ & $330 / 350$ & $21.8 / 27.5$ & $50.0 / 57.0$ & $880 / 1000$ \\
\hline \multicolumn{6}{|c|}{ Rolling fork forgings, steel $40 \mathrm{CrSi}$} \\
\hline 5 & $1029 / 1050$ & $860 / 925$ & $16.7 / 16.5$ & $48.4 / 52.0$ & $560 / 560$ \\
\hline 6 & 925/941 & $720 / 740$ & $20.5 / 21.0$ & $61.9 / 62.5$ & $990 / 1360$ \\
\hline
\end{tabular}

Note: 1, 3, 5 forgings mechanical characteristics obtained by PTMP modes; 2, 4, 6, factory modes.

\section{Features and Benefits}

The data shows that PTMP compared with standard processing improves the mechanical properties of steels. Production of large and complex forgings and weighing up to $12 \mathrm{~kg}$ of steel $45,33 \mathrm{CrSi}$ and $40 \mathrm{CrSi}$ provides increased strength characteristics (tensile strength and flow stress) with increase or maintaining the characteristics of ductility and toughness.

Possible application features:

PTMP technology application allows achieving specific micro-grain structure condition characterized by the creation of dynamic polygonized crystalline lattice of alloy that 
improves the set of mechanical properties.

The developed technology is the most efficiently used in the conditions of large-scale production of forgings on hammers and press machines. For example, in the mass stamping production of case details, or flanges, as well as for extrusion processing of sleeves, cups or pipes with a complex cross-section profile. This allows reducing the mechanical load on the working elements of stamping machines (punch, die), increasing and extending the operational life, and at the same time giving the material of workpieces crucial mechanical characteristics.

\section{Conclusion}

The technologically rational and suitable micro-grain structural condition of material has an accurate grain formation with an equable distribution of crystalline lattice imperfections throughout the material volume that only PTMP allows to achieve.

Programmed thermo-mechanical processing is one of the ways to improve the structural strength of products primarily by optimizing the micro-grain structure of material.

Programmed thermo-mechanical processing results in a large-scale hot die punching of forgings made of alloy steels with increased complex of mechanical properties compared to the manufactured forgings by factory modes. (table 2 ). At the same time, it allows to reduce the damage rate on working elements of stamping equipment (punch, die), increasing operating equipment lifetime.

\section{References}

[1] Bernshtein M. L. Thermomehanicheskaya obrabotka metallov i splavov. Moskva: Metallurgia. 1996. Vipusk 1. 1171 s. (rus).

[2] Starodubov K. F. Uprochnyaushaya termicheskaya i temomehanicheskaya obrabotka prokata. Kiev: Tehnika, 1968, s. 6-8 (rus).

[3] Radkevich M. M. Uprochnenie uglerodistih I legirovannih stalei pri shtampovke $\mathrm{v}$ otkritih shtampah s primeneniem VTMO. // Vestnik mashinostroeniya. № 6. 1985 s. 18-21 (rus).
[4] Trefilov V. I. Fizika deformacionnogo uprochneniya monokristalov. Kiev. Naukova dumka. 1972. 191 s (rus).

[5] Bernstein M. L. Goryachaya plasticheskaya deformaciya i mehanizm uprochneniya stali pri TMO. // Stal'. №. 2. 1972. s. 157-165 (rus).

[6] Radkevich M. M. Fiziko-tehnologicheskie osnovi yprochnyaushei PMTO. // Perspektivnie tehnologicheskie processi obrabotki metallov. S. Peterburg. 1995. s. 54-57 (rus).

[7] Radkevich M. M. Radkevich I. M. Raznozernistost' structuri termouprochnennih pokovok. // Nauka proizvodstvu. № 1. 1998. s. 17-19 (rus).

[8] Radkevich M. M. Vliyanie yslovii ohlagdeniya na mehanicheskie svoistva pri PMTO. // Vestnik machinostroeniya. № 12. 1999. s. 50-53 (rus).

[9] Radkevich M. M. Programmnoe deformacionno-termicheskoe uprochnenie I odnorodnost' raspredeleniya dislokacii. Moskva.: Sinergetika, struktura I svoistva materialov, samoorganizuushiesya tehnologii. 1996. s. 23-25 (rus).

[10] Radkevich M. M., Parshin A. M., Kamishanchenko N. V. Vliyanie programmnoi deformacionno-termicheskoi obrabotki na odnorodnost' plasticheskoi deformacii. // Nauchnie vedomosti BGU. №1 (10). 2000. Seriya Fizika. s. 75-79 (rus).

[11] Radkevich M. M. Vliyanie uslovii ohlagdeniya na poluchaemii uroven' mehsvoistv stalei pri PMTO. // Vestnik mashinostroeniya. №12. 1999. s. 37 (rus).

[12] Radkevich M. M., Radkevich I. M. Tehnologiya programmnoi mehaniko-termicheskoi obrabotki konstrukcionnih stalei. // Metalloobrabotka. №1 (10). 2001. s. 54-58 (rus).

[13] Radkevich M. M., Radkevich I. M. Kombinirovannaya obrabotka visokoprochnih izdelii iz konstrukcionnih stalei. // Tehnika mashinostroeniya. №6 (28). 2000. Seriya Fizika. s. 43-48 (rus).

[14] Radkevich M. M. Osobennosti formirovaniya ochaga plasticheskoi deformacii v usloviyah DTO. // Kuznechnoshtampovochnoe proizvodstvo. №2. 2001. s. 18-23 (rus).

[15] Radkevich M. M. Tehnologicheskie aspekti uprochnyaushei programmnoi mehaniko-termicheskoi obrabotki. // FGAOU VO "SpbPU Petra Velikogo", S. Peterburg, izdatel'stvo politegnicheskogo universiteta. 2020. s. 205. (rus). 